\title{
SWISHMAX DALAM PENGEMBANGAN MEDIA PEMBELAJARAN STRUKTUR ALJABAR
}

\section{SWISHMAX IN THE DEVELOPMENT OF ALGEBRA STRUCTURE LEARNING MEDIA}

\author{
Reni Ulfa Sari", Farida, Siska Andriani dan Bambang Sri Anggoro \\ Program Studi Pendidikan Matematika Fakultas Tarbiyah dan Keguruan UIN Raden Intan Lampung, Indonesia \\ *Email: reniulfasari16@gmail.com
}

Diterima: 14 Desember 2019. Disetujui: 8 Januari 2020. Dipublikasikan: 14 Juni 2020

\begin{abstract}
Abstrak: Penelitian ini bertujuan untuk menghasilkan media pembelajaran berbantuan swishmax pada materi grup dan subgrup, mengetahui kelayakan produk serta respon mahasiswa untuk mencapai pembelajaran yang efektif, efisien dan menarik. Metode penelitian ini adalah Research and Development (R\&D) berdasarkan model 4D yang terdiri dari 4 tahapan, yaitu Define, Design, Development, and Disseminate. Subyek penelitian ini adalah mahasiswa jurusan pendidikan matematika UIN Raden Intan Lampung. Data penelitian diperoleh dengan teknik wawancara, angket, observasi, dan tes. Hasil penilaian validasi ahli materi terhadap media ini termasuk dalam kategori valid dengan skor rata-rata sebesar 3,51 dari rata-rata skor tertinggi 4,00. Penilaian ahli media terhadap media ini termasuk dalam kategori valid dengan skor rata-rata sebesar 3,49 dari skor rata-rata tertinggi 4,00. Pada uji coba kemenarikan skala kecil yang diikuti oleh 10 mahasiswa kelas VD memperoleh skor rata-rata yaitu 3,43 dari skor tertinggi dengan rata-rata 4,00 berdasarkan hasil dari angket kemenarikan media pembelajaran swishmax merupakan kriteria sangat menarik. Pada uji coba lapangan skala besar yang diikuti oleh 31 mahasiswa kelas VC skor rata-rata kemenarikan yang diperoleh yaitu 3,37 pada kriteria sangat menarik. Kualitas keefektifan produk dilihat dari tes hasil belajar. Hasil penelitian dan pengolahan data menggunakan uji effect size dengan hasil 0,70 dengan kriteria sedang. Berdasarkan hasil tersebut dapat disimpulkan bahwa Media Pembelajaran Matematika Berbantuan Swishmax Pada Materi Grup dan Subgrup layak dan efektif untuk dijadikan alat bantu pembelajaran.
\end{abstract}

Kata Kunci: Pengembangan, Media Pembelajaran, Swishmax, Grup, Subgrup

\begin{abstract}
This study aims to produce swishmax-assisted learning media for section of group and subgroup, to find out the product's feasibility and student responses to achieve effective, efficient and interesting learning. The method of this research is research and development (R\&D) based on the 4D model which consists of 4 steps: Define, Design, Development, and Disseminate. The subjects of this research were students in mathematics education major at UIN Raden Intan Lampung. The research data obtained by interview techniques, observation questionnaires, and tests. The results of the materrial expert validation assessment of this media are included in the valid category with an average score of 3.51 from the highest average score of 4.00 . The assessment by media expert of this media is included the valid category with an average score of 3.49 from the highest average score of 4.00 . In the small scale attractiveness trial which was followed by 10 students of VD class, the average score was 3.43 from the highest score of 4.00 based on the results of the attractiveness questionnaires of the swishmax learning media are very interesting criteria. In the large scale field trial which was attended by 31 students of $\mathrm{VC}$ class, the average score of attractiveness was 3.37 on very interesting criteria. The quality of the effectiveness product is seen from the test of learning outcomes. The results of research and data processing using the effect size test with the results of 0.70 in medium criteria. Based on these results it can be concluded that the mathematics learning media assisted by swishmax in the section of group and subgroup is effective and feasible to be used as alearning aid.
\end{abstract}

Keywords: Development, Learning Media, Swishmax, Group, Subgroup

\section{PENDAHULUAN}

Pendidikan merupakan hal yang penting bagi peserta didik untuk maju dan memiliki tingkat kesejahteraan yang tinggi [1]. Pendidikan merupakan investasi masa depan yang menjamin kemajuan kehidupan. Kualitas pendidikan menggambarkan kualitas SDM (Sumber Daya Manusia) sebagai investasi utama masa depan [2]. Matematika merupakan cabang ilmu pengetahuan yang memainkan peran peting dalam pendidikan [3]. Dengan pendidikan tersebut membuat manusia mengembangkan dirinya sehingga mampu menghadapi setiap perubahan yang terjadi akibat adanya kemajuan ilmu pengetahuan dan teknologi [4]. Fungsi pendidikan adalah betuk dari pegembangan kemampuan, bentuk sikap dan perilaku setiap orang untuk menjadi manusia beriman dan taqwa kepada Tuhan Yang Maha Esa, berakhlak mulia, berilmu, memiliki keterampilan dan berakal [5].

Perkembangan Teknologi Informasi dan Komunikasi (TIK) sangat pesat di berbagai bidang kehidupan. Bidang pendidikan pun tidak luput dari perkembangan Teknologi Informasi dan Komunikasi (TIK). Menurut Nur Ani dan Istiqomah Salah satu 
pemanfaatan Teknologi Informasi dan Komunikasi dalam bidang pendidikan yaitu penggunaan multimedia sebagai alat penunjang proses pembelajaran [6].

Pembelajaran berbasis multimedia ini dapat menyajikan materi pembelajaran yang lebih mudah, menarik, tidak monoton. Peserta didik juga dapat mempelajari materi pelajaran tertentu secara mandiri dengan komputer yang dilengkapi program multimedia [7]. Multimedia adalah media yang mengkombinasikan elemen-elemen berupa teks, grafis, gambar, foto, audio, video dan animasi secara terintegrasi menggunakan komputer [8]. Untuk mencapai hal ini maka pendidik perlu diberikan informasi tentang media pembelajaran berbasis multimedia yang disusun dengan menggunakan program swishmax agar dapat dipergunakan di kelas dengan cara yang menarik untuk mempromosikan jenis penguasaan era digital, memicu kreativitas, melibatkan rasa ingin tahu, serta meningkatkan hasil belajar [9]. Jadi, penggunaan multimedia program swishmax ini mampu menjanjikan untuk digunakan dalam bidang pendidikan serta proses pembelajaran.

Adapun kelebihan dan kekurangan software swishmax sebagai berikut:

a. Kelebihan software swishmax antara lain:

1. Software swishmax relatif lebih mudah digunakan dibandingkan macromedia flash dan dengan hasil relatif sama swishmax sudah dilengkapi dengan berbagai animasi yang menarik dan mudah dalam penggunaannya.

2. Software swishmax dapat menstimulasikan efek gerak. Dapat diberi suara dan warna.

3. Dapat mendesain konten pelajaran menjadi lebih kratif dan inovatif.

4. Software swishmax juga mampu menangani link antara objek maupun dokumen.

5. Software swishmax juga dapat melakukan import file animasi seperti animasi flash.

b. Kekurangan software swishmax antara lain:

1. Memerlukan peralatan khusus dalam penyajian.

2. Memerlukan keterampilan khusus dalam pembuatan.

3. Memerlukan tenaga listrik [10].

Berdasarkan penelitian sebelumnya yang membahas tentang pengembangan media diantaranya pengembangan media komik berbasis android oleh Regita Anesia, Bambang Sri Anggoro, dan Indra Gunawan [11]. Pengembangan media pembelajaran berbasis ICT menggunakan macromedia flash oleh Aquami, Muhamad Afandi, dan Andi Putra Sairi [12]. Pengembangan media pembelajaran audio visual program microsoft power pada siswa SMP oleh Ida Ayu Putu Armyani, Didik Martedi [13]. Pengembangan media pembelajaran dengan swishmax pada siswa SMA oleh Purbo Suwansono Kharisma
Resi Pradipta, Widjianto [14]. Berbeda dengan penelitian sebelumnya, penelitian ini bertujuan untuk mengetahui kelayakan produk serta respon mahasiswa untuk mencapai pembelajaran yang efektif, efisien dan menarik swishmax dalam pengembangan media pembelajaran sruktur aljabar.

Sehingga seiring perkembangan zaman, model pembelajaran perlu dimodifikasi untuk beradaptasi dengan era digitalisasi abad 21 yaitu pemanfaatan teknologi [15]. Penggunaan Software dalam pengembangan media pembelajaran merupakan pemanfaatan TIK yang saat ini berkembang sangat pesat salah satu nya adalah Software Swishmax. Penggunaan swishmax tidaklah serumit macromedia flash yang mampu menangani berbagai macam pembuatan animasi, bahkan macromedia flash bisa digunakan untuk pembuatan film animasi kartun. Swishmax merupakan suatu program untuk mendesain grafis animasi dengan teks, gambar, suara dengan mudah dan cepat dalam bentuk audio visual yang menghasilkan animasi flash.

Beberapa penjelasan diatas peneliti akan melakukan pengembangan media pembelajaran yang menggunakan Swishmax. Namun, sebelum itu peneliti melakukan prasurvey wawancara terhadap salah satu dosen pendidikan matematika di UIN Raden Intan Lampung, STKIP PGRI Bandar Lampung, dan Universitas Muhammadiyah Metro. Hasil wawancara menyimpulkan bahwa media pembelajaran yang berbasis teknologi perlu untuk dikembangkan sebagai pemanfaatan perkembangan TIK dengan baik apalagi pada materi struktur aljabar yang masih jarang menggunakan media pembelajaran dalam proses pembelajaran.

Peneliti memperoleh sumber referensi dari penelitian terlebih dahulu sebagai acuan untuk penelitian ini. Menurut Arda, Sahrul Saehana, dan Darsikin penelitiannya terhadap pengembangan media pembelajaran interaktif berbasis komputer mendapatkan respon yang baik dari siswa serta membuat siswa sangat berminat dan termotivasi untuk belajar [16]. Pembelajaran menggunakan media belajar matematika berbasis multimedia interaktif layak digunakan dan dapat dimanfaatkan sebagai salah satu sumber belajar bagi siswa [17]. Sedangkan menurut Asro Nur Aini, Bambang Sri Anggoro, dan Fredi Ganda Putra pengembangan media pembelajaran matematika dinyatakan layak dan menarik digunakan pada mahasiswa berdasarkan hasil angket respon ketertarikan [18]. Dan hasil penelitian penggunaan media pembelajaran interaktif dengan menggunakan Software Swishmax mendapatkan respon positif [19].

Merujuk penjelasan diatas, peneliti akan melakukan penelitian dengan mengembangkan media pembelajaran interaktif menggunakan Software Swishmax-4 pada pembelajaran Struktur Aljabar. 


\section{METODE PENELITIAN}

Jenis penelitian ini adalah penelitian dan pengembangan $(R N D)$. Prosedur yang digunakan dalam penelitian dan pengembangan ini adalah 4D. Tahapan-tahapan nya dapat dilihat pada Gambar 1 [20].

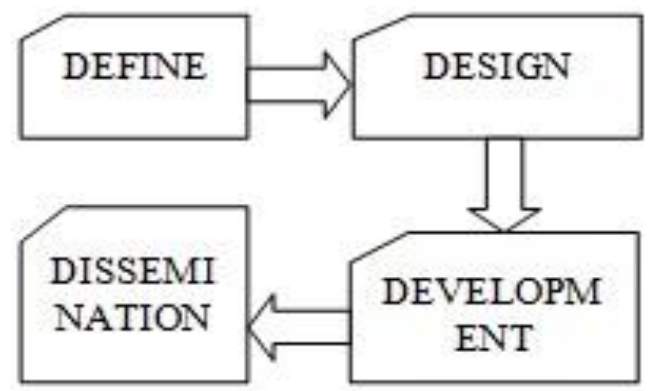

Gambar 1. Tahapan 4D

Teknik pengumpulan data yang digunakan penulis adalah wawancara, penyebaran angket dan tes. Angket yang digunakan adalah angket validasi kepada para pakar ahli dan angket peserta didik. Adapun data kualitatif dihasilkan dari saran dan masukan para pakar ahli sedangkan data kuantitatif dihasilkan dari hasil validasi dan tes yang telah dilakukan. Teknik pengolahan data yang digunakan dalam pengolahan data hasil tes adalah teknik uji effect size. Rumus yang digunakan sebagai berikut [21].

$$
d=\frac{M_{\text {posttest }}-M_{\text {pretest }}}{\sqrt{\frac{S D_{\text {posttest }}^{2}+S D_{\text {pretest }}^{2}}{2}}}
$$

Keterangan:

$M=$ rata-rata skor test

$S D=$ standar devisiasi skor test

$d=$ nilai effect size

\section{HASIL DAN PEMBAHASAN}

Hasil pengembangan yang dilakukan oleh peneliti adalah menghasilkan media media pembelajaran interaktif menggunakan Software Swishmax-4 pada pembelajaran Struktur Aljabar dengan menggunakan prosedur 4 tahap yang dinamakan 4D (Four-D).

\section{Define (Pendefinisian)}

Tahap pendefinisian ini mencakup empat langkah pokok, yaitu analisis Front-end (front-end analysis), analisis konsep (Concept analysis), analisis tugas (task analysis), dan perumusan tujuan pembelajaran (specifying instructional objectives). Analisis Front-end (front-end analysis) dilakukan dengan dua langkah yaitu menyebar angket analisis kebutuhan dan wawancara di UIN Raden Intan Lampung, STKIP PGRI Bandar Lampun dan UM Metro. Hasil yang diperoleh mahasiswa membutuhkan media pembelajaran matematika menggunakan swishmax membantu mahasiswa dan memudahkan dosen dalam menyampaikan pembelajaran.

Analisis konsep yang telah dilaksanakan ialah untuk mengetahui faktor penting dan utama yang nanti dipelajari serta menyusunnya pada format yang terorganisasi dan relavan yang akan ada di media pembelajaran. Pada analisis tugas dilakukan analisis kompetensi dasar kemudian menjabarkan indikator pembelajaran. Analisis tugas akan menunjang dalam memilih bentuk serta format media yang ingin dikembangkan. Selanjutnya analisis tujuan pembelajaran yaitu merangkum hasil dari analisis konsep dan analisis tugas untuk membuat sebuah media pembelajaran yang menarik, relevan dengan materi ajar, dapat membangkitkan minat belajar mahasiswa serta mempermudah pemahaman mahasiswa terhadap objek penelitian.

\section{Design (Perancangan)}

Tahap Define telah dilakukan dan mendapatkan masalah dan potensi yang digunakan sebagai acuan untuk tahap design (perencanaan). Tahap ini design merupakan tahap pembuatan rancangan awal media pembelajaran menggunakan aplikasi Swishmax-4 yang berbentuk video. Berikut ini Gambar.2 dan Gambar.3 tampilan rancangan awal media.

\section{Development (Pengembangan)}

Tahap Development atau pengembangan adalah tahapan penilaian dan pengujian terhadap media pembelajaran menggunakan aplikasi Swishmax-4. Penilaian yang pertama adalah validasi dengan masing-masing 3 dosen Ahli Materi dan Ahli Media. Hasil validasi dapat dilihat pada tabel 1 dan tabel 2.

Berdasarkan tabel hasil validasi tahap 1 oleh ahli materi dan ahli media didapatkan nilai dengan kategori Cukup Valid maka media belum didapat digunakan pada penelitian karena belum dikategorikan layak dan perlu dilakukan perbaikan. Berikut ini gambar perbaikan yang dilakukan peneliti berdasarkan saran dan komentar dari ahli materi dan media. 


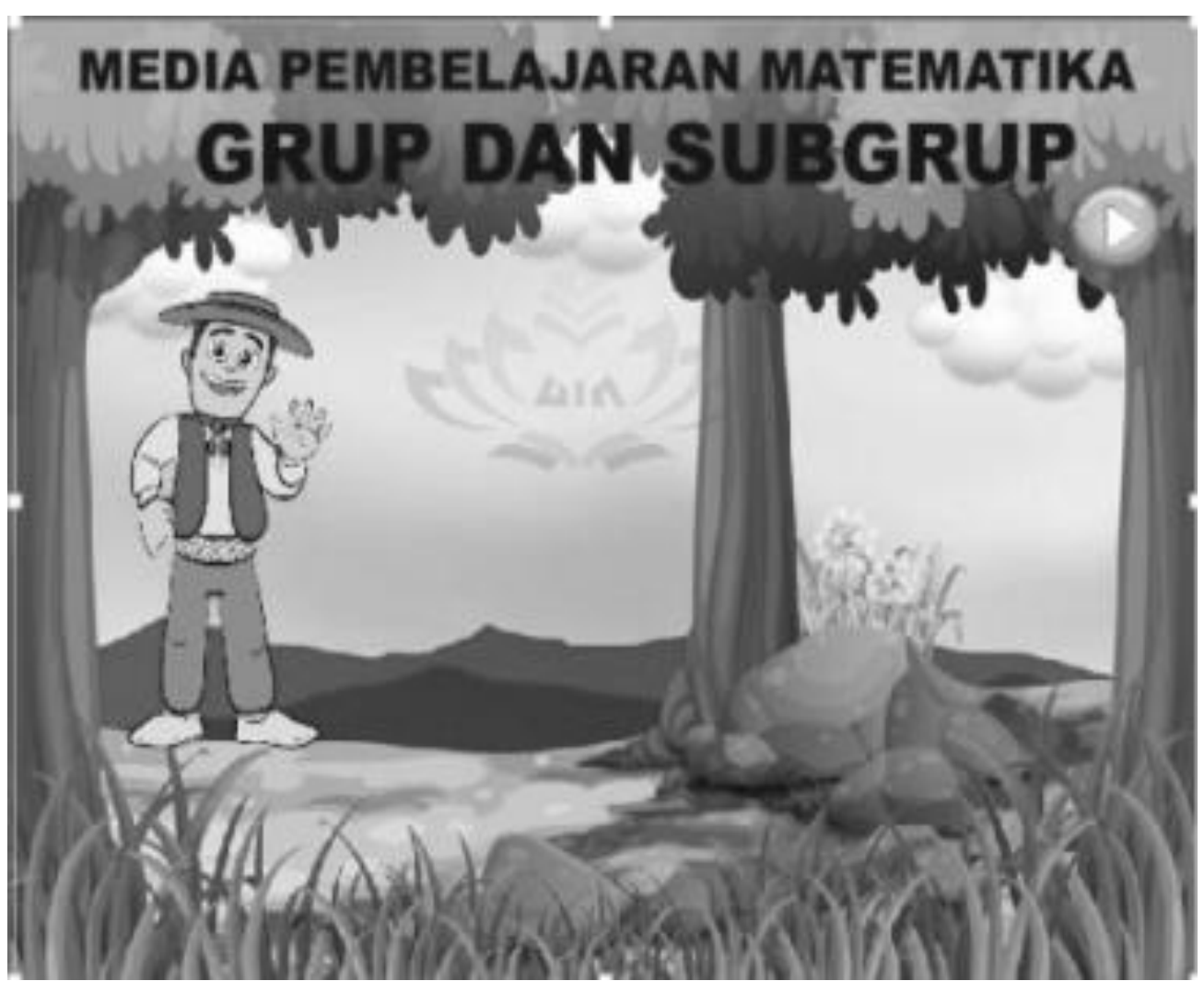

Gambar 2. Tampilan Awal Media

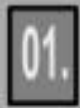

Dalam sistem aljabar terdapat jenis himpunan Grup, dibawah ini terdapat syarat-syarat himpunan grup, kecuali?

\section{(A) Tidak terdapat elemen identitas}

B Operasi bersifat asosiatif

(C) Himpunan tertutup dibawah suatu operasf

D) Setiap anggota himpunan memiliki in ers untuk operasi

Gambar 3. Tampilan Awal Soal Media 
Tabel 1. Hasil validasi ahli materi tahap 1

\begin{tabular}{lcc}
\hline \multicolumn{1}{c}{ Aspek } & Skor & Keterangan \\
\hline Kualitas Isi & 2,67 & Cukup Valid \\
Keterlaksanaan & 2,67 & Cukup Valid \\
Kebahasaan & 2,78 & Cukup Valid \\
\hline
\end{tabular}

Tabel 2. Hasil validasi ahli media tahap 1

\begin{tabular}{lcl}
\hline \multicolumn{1}{c}{ Aspek } & Skor & Keterangan \\
\hline Tampilan Media & 2,91 & Cukup Valid \\
Fungsi tombol & 3,16 & Cukup Valid \\
Penggunaan & 2,89 & Cukup Valid \\
\hline
\end{tabular}

Gambar 4 dan 5 adalah hasil sebelum dan setelah perbaikan. Perbaikan yang ditunjukkan gambar adalah bagian latihan lebih diperjelas. Setelah media diperbaiki sesuai dengan saran dan masukan para ahli maka selanjutnya media divalidasikan kembali. Hasil validasi tahap 2 terdapat pada tabel 3 dan tabel 4.

Berdasarkan hasil validasi kedua pada tabel 5 , hasil validasi diperoleh skor rata-rata pada kriteria valid, sehingga disimpulkan bahwa media sudah layak digunakan sebagai bahan ajar dan dapat dilakukan uji coba lapangan.

Tahap kedua pada pengembangan adalah uji coba yang dilakukan pada 2 skala berbeda yaitu skala besar dan skala kecil. Skala kecil dilakukan uji coba kemenarikan terdiri dari 10 mahasiswa di semester V kelas D dengan hasil uji coba 3,43 dalam kriteria sangat menarik. Sedangkan uji pada skala besar dengan 31 responden pada semester $\mathrm{V}$ kelas $\mathrm{C}$ dengan skor 3,37 pada kriteria sangat menarik. Berdasarkan hasil uji kemenarikan media diatas maka disimpulkan media yang sudah dikembangkan sangat menarik untuk digunakan dalam proses pembelajaran struktur aljabar. Selanjutnya dilakukan uji efektifitas dengan uji effect size.Uji keefektifan ini dilakukan kepada mahasiswa prodi pendidikan matematika UIN Raden Intan Lampung.

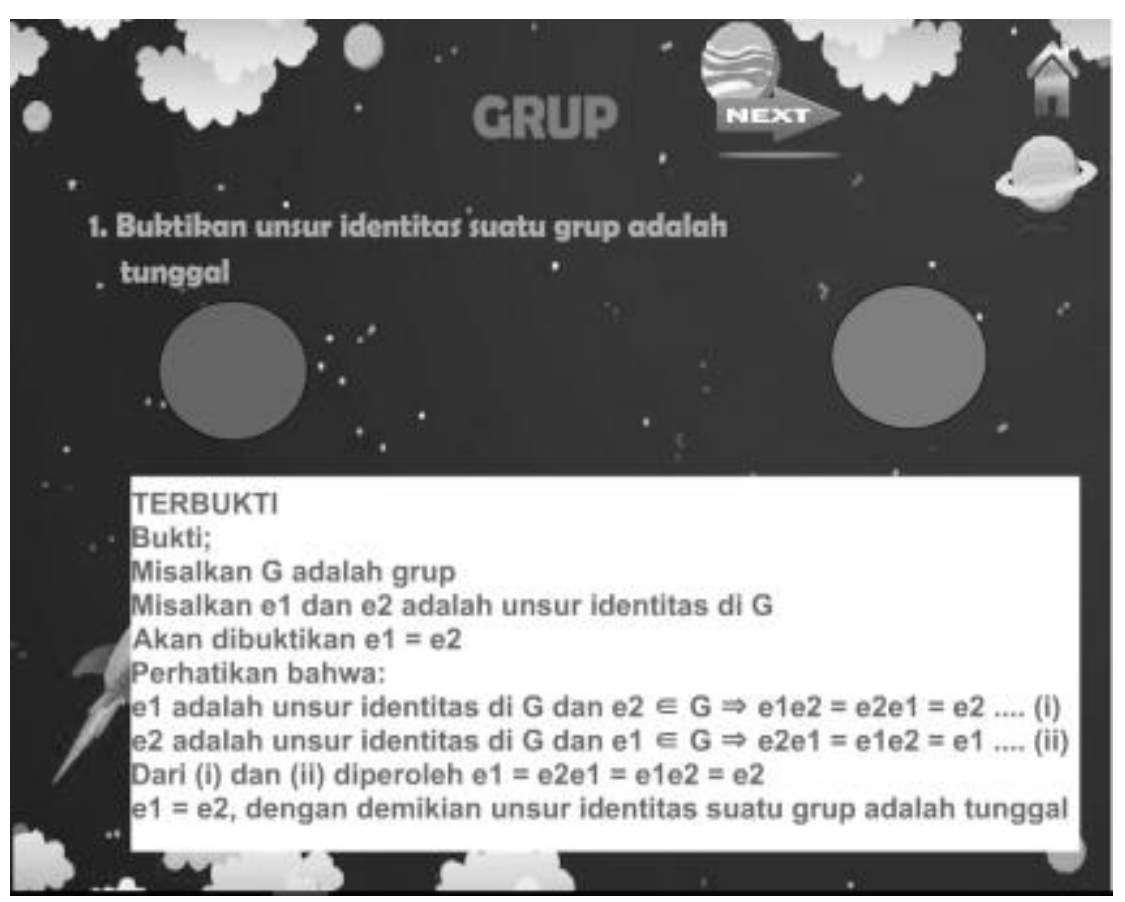

Gambar 4. Sebelum Revisi 


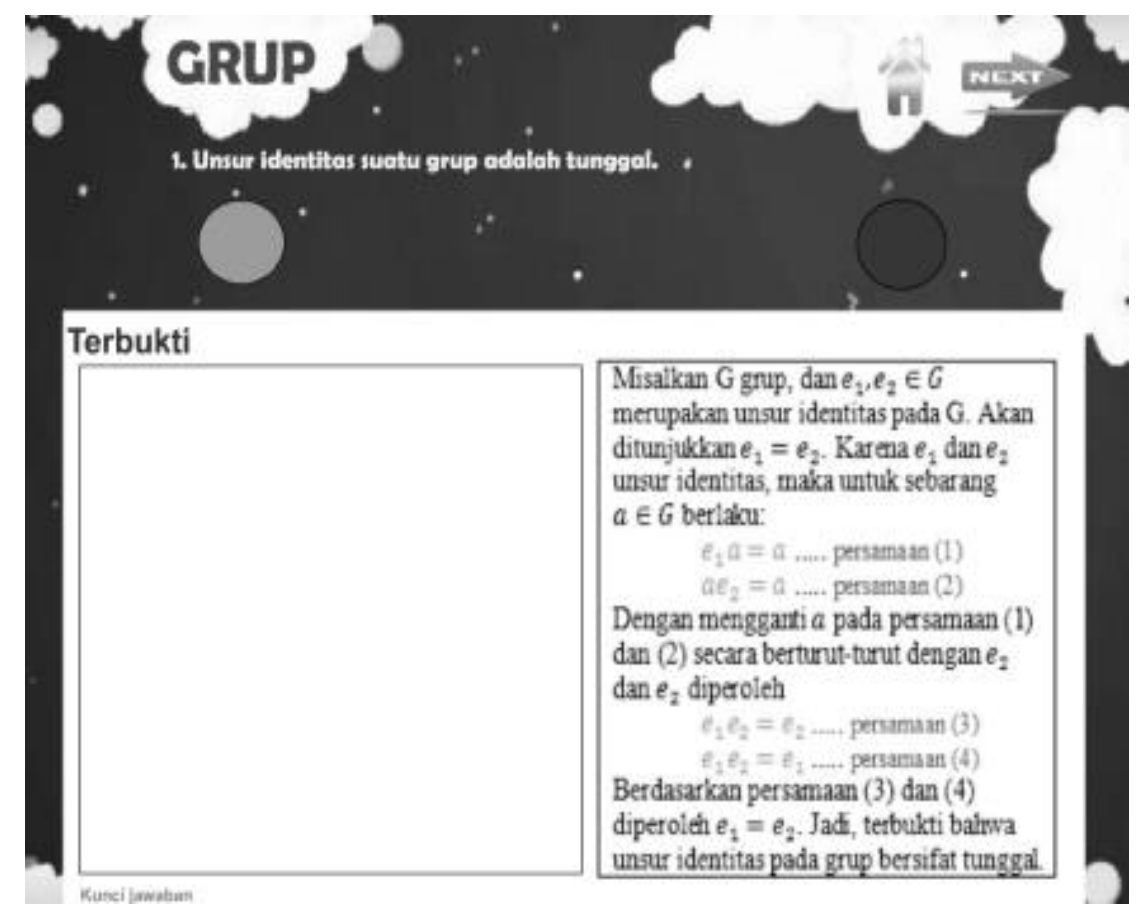

Gambar 5. Sesudah Revisi

Tabel 3. Hasil validasi ahli materi

\begin{tabular}{lcc}
\hline \multicolumn{1}{c}{ Aspek } & Skor & Keterangan \\
\hline Kualitas Isi & 3,47 & Valid \\
Keterlaksanaan & 3,5 & Valid \\
Kebahasaan & 3,56 & Valid \\
\hline
\end{tabular}

Tabel 4. Hasil validasi ahli media tahap 2

\begin{tabular}{lcc}
\hline \multicolumn{1}{c}{ Aspek } & Skor & Keterangan \\
\hline Tampilan Media & 3,47 & Valid \\
Fungsi tombol & 3,33 & Valid \\
Penggunaan & 3,67 & Valid \\
\hline
\end{tabular}

Tabel 5. Data Hasil Perhitungan Pretest dan Posttest Kelas VC

\begin{tabular}{cccccc}
\hline & $N$ & Skor Maksimum & $\begin{array}{c}\text { Skor } \\
\text { Minimum }\end{array}$ & $\begin{array}{c}\text { Skor } \\
\text { Rata-Rata }\end{array}$ & $\begin{array}{c}\text { Standar } \\
\text { Devisiasi }\end{array}$ \\
\hline Pretest & 31 & 60 & 10 & 31,77 & 33,58 \\
Posttest & 31 & 85 & 45 & 70,32 & 69,78 \\
\hline
\end{tabular}

Hasil analisis data untuk kelas V C memperoleh nilai $E_{S}=0,70$. Berdasarkan kategori yang di tentukan tingkat keefektivitas media pembelajaran menggunakan swishmax pada materi Grup dan Subgrup dikategorikan cukup efektif dengan kalsifikasi terfolong sedang. Dengan kategori yang diperoleh pada uji keefektifan media pembelajaran memberikan pengaruh sebagai alat bantu dalam proses belajar mengajar.

\section{KESIMPULAN}

Kesimpulan dari penelitian Media pembelajaran matematika berbantuan swishmax pada materi grup dan subgrup yang dihasilkan telah dikembangkan dengan model pengembangan 4D. Hasil angket dan respon mahasiswa mengenai kelayakan serta kemenarikan media pembelajaran berbantuan swishmax memperoleh skor rata-rata ahli materi sebesar 3,51, dan skor rata-rata ahli media sebesar 3,49 untuk hasil angket respon mahasiswa memperoleh skor uji coba skala kecil sebesar 3,43 dan 
skor uji coba skala besar sebesar 3,37 dengan kriteria sangat menarik. Hasil uji effect size yang dilaksanakan di semester V kelas $\mathrm{C}$ memperoleh $E_{S}=0,70$. Dari data yang diperoleh kedua hasil menunjukkan bahwa pengembangan media yang dikembangkan layak dan efektif dipakai sebagai media pembelajaran guna membantu mahasiswa dalam proses pembelajaran.

\section{DAFTAR PUSTAKA}

[1] Wisudawan, Wahyudin, Benny Hendriana, Ishaq Nuriadin, and Harry Ramza, (2017). Pengembangan Aplikasi Math Mobile Learning Bangun Datar Berbasis Android Pada Materi Segitiga Dan Segiempat Pelajaran Matematika Di Tingkat SMP. Seminar Nasional TEKNOKA, 2 1-13

[2] Indariani, Artisa, Nur Ayni, Surya Amami Pramuditya, and Muchamad Subali Noto (2019). Teknologi Buku Digital Matematika Dan Penerapan Potensialnya Dalam Distance Learning. Jurnal Nasional Pendidikan Matematika, 3, 1-12

[3] Ratnasari, Nining, Nilawati Tadjudin, Muhammad Syazali, Mujib, and Siska Andriani. (2018). Project Based Learning (PbBL) Model on the Mathematical Representation Ability. Tadris: Jurnal Keguruan Dan Ilmu Tarbiyah, 3, Nomor 1, 4753.

[4] Putra, R.W.Y., \& Ruli, A. (2016). Pengembangan Bahan Ajar Materi Trigonometri Berbantuan Software iMindMap pada Siswa SMA. Al-Jabar: Jurnal Pendidikan Matematika, 7(1), 39-47.

[5] Sari, Fiska Komala, Farida, and M.Syazali (2016). Pengembangan MediaPembelajaran (Modul) Barbantuan Geogebra Pokok Bahasan Turunan. Al-Jabar: Jurnal Pendidikan Matematika, 7.

[6] Lestari, Nur Ani, and Istiqomah, "Pengembangan Multimedia Pembelajaran Kurikulum 2013 Pada Pokok Bahasan Trigonometri Di SMK", Union: Jurnal Pendidikan Matematika, 5 (2017), 253-62

[7] Hadiprayitno, Gito, and Muh. Makhrus (2012). Pengembangan Media Pembelajaran Macromedia Flash Berorientasi Pembelajaran IPA Terpadu Tipe Connected. J. Pijar MIPA, Volume 6, Nomor 2.

[8] Surachman, Mardhika, Muntari, and Lalu Rundyat Telly Savalas (2014). Pengembangan Multimedia Interaktif Berbasis Kontekstual Untuk Meningkatkan Penguasaan Konsep Dan Keterampilan Berpikir Kritis Siswa Kelas XI Pada Materi Pokok Sistem Koloid. J. Pijar MIPA, Volome 9, Nomor 2.

[9] Hendriyani, Yeka, Vera Irma Dekianti, and Lativa Mursyida (2017). Persepsi Penggunaan
Swishmax Untuk Pengembangan Media Pembelajaran Oleh Guru Sekolah Dasar Di Gugus 3 Kamang Magek Kabupaten Agam. Jurnal Teknologi Informasi \& Pendidikan, Volume 10, Nomor 3.

[10] Riska, Dispi, Muhammad Afandi, and Mardiah Astuti (2019). Pengemabngan Media Pembelajaran Ilmu Pengetahuan Alam Berbasis Swishmax Di MIN 2 Palembang. AlMudarris: Journal of education, Volume 2, Nomor 2.

[11] Anesia, Regita, Bambang Sri Anggoro, and Indra Gunawan (2018). Pengembangan Media Komik Berbasis Android Pada Pokok Bahasan Gerak Lurus. Indonesia Journal of Science and mathematic Education 1(1), 53-57.

[12] Aquami, Muhamad Afandi, and Andi Putra Sairi (2019). Pengembangan Media Pembelajaran Berbasis ICT Menggunakan Macromedia Flash Pada Mata Pelajaran IPA MI/SD. Al-Mudarris Journal Of Education, Volume 2 Nomor 1.

[13] Armyani, Ida Ayu Putu, and Didik Martedi (2015). Pengembangan Media Pembelajaran Audio Visual Program Microsoft Power Point Pada Pokok Bahasan Organisasi Kehidupan Kelas VII SMP Negeri 19 Mataram Tahun Pelajaran 2012/2013. J. Pijar MIPA, 10(2)

[14] Pradipta Purbo Suwansono Kharisma Resi, Widjianto (2016). Pengembangan Media Pembelajaran Fisiska Berbasis Multimedia Dengan Swishmax 4 Pada Materi Kinematika Gerak Lurus Untuk Siswa SMA, 13.

[15] Ihsan, M. S., Ramdani, A., and Hadisaputra, S. (2019). Pengembangan E-Learning Pada Pembelajran Kimia Untuk Meningkatkan Kemampuan Berpikir Kritis Peserta Didik. $J$. Pijar MIPA, 14(2), 84-87

[16] Arda, Sahrul Saehana, and Darsikin (2015). Pengembangan Media Pembelajaran Interaktif Berbasis Komputer Untuk Siswa Smp Kelas Viii. E-Jurnal Mitra Sains, 1, 69-77

[17] Siamy, Lailatul, Farida, and Muhamad Syazali (2018). Media Belajar Matematika Berbasis Multimedia Interaktif Dengan Pendekatan Contextual Teaching and Learning. Desimal: Jurnal Matematika, 1, 113-17

[18] Aini, Asro Nur, Bambang Sri Anggoro, and Fredi Ganda Putra (2018). Pengembangan Media Pembelajaran Matematika Pada Materi Transportasi Berbantuan Sparkol. UNION: Jurnal Pendidikan Matematika, 6, 287-96

[19] Maulana, Hutomo Atman (2017). Pengembangan Media Pembelajaran Interaktif Dengan Menggunakan Pengembangan Media Pembelajaran Interaktif Dengan Menggunakan Software Swishmax Pada Materi Segiempat Kelas VII SMP. MATH EDUCA: Jurnal 
Matematika Dan Pendidikan Matematika, 1, 37-50

[20] Sugiono. (2017). Metode Penelitian \& Pengembangan Research and Development' Bandung: Alfabeta. 37-38

[21] Budiyono, Agus (2016). Pengaruh Penerapan Model Pembelajaran Argument Based Science Inquiry (ABSI) Terhadap Peningkatan Kemampuan Berargumentasi. Jurnal Pemikiran Penelitian Pendidikan Dan Sains, 4 No.1, 84-93. h. 88. 